University of Montana

ScholarWorks at University of Montana

Ecosystem and Conservation Sciences Faculty

Publications

Ecosystem and Conservation Sciences

2004

\title{
El Niño-Southern Oscillation-Induced Variability in Terrestrial Carbon Cycling
}

Hirofumi Hashimoto

Ramakrishna R. Nemani

Michael A. White

William M. Jolly

Steve C. Piper

See next page for additional authors

Follow this and additional works at: https://scholarworks.umt.edu/decs_pubs

Part of the Ecology and Evolutionary Biology Commons

Let us know how access to this document benefits you.

\section{Recommended Citation}

Hashimoto, Hirofumi; Nemani, Ramakrishna R.; White, Michael A.; Jolly, William M.; Piper, Steve C.; Keeling, Charles D.; Myneni, Ranga B.; and Running, Steven W., "El Niño-Southern Oscillation-Induced Variability in Terrestrial Carbon Cycling" (2004). Ecosystem and Conservation Sciences Faculty Publications. 23.

https://scholarworks.umt.edu/decs_pubs/23

This Article is brought to you for free and open access by the Ecosystem and Conservation Sciences at ScholarWorks at University of Montana. It has been accepted for inclusion in Ecosystem and Conservation Sciences Faculty Publications by an authorized administrator of ScholarWorks at University of Montana. For more information, please contact scholarworks@mso.umt.edu. 


\section{Authors}

Hirofumi Hashimoto, Ramakrishna R. Nemani, Michael A. White, William M. Jolly, Steve C. Piper, Charles D. Keeling, Ranga B. Myneni, and Steven W. Running 


\title{
El Niño-Southern Oscillation-induced variability in terrestrial carbon cycling
}

\author{
Hirofumi Hashimoto, ${ }^{1}$ Ramakrishna R. Nemani, ${ }^{2}$ Michael A. White, ${ }^{3}$ William M. Jolly, ${ }^{4}$ \\ Steve C. Piper, ${ }^{5}$ Charles D. Keeling, ${ }^{5}$ Ranga B. Myneni, ${ }^{6}$ and Steven W. Running ${ }^{4}$ \\ Received 26 April 2004; revised 15 September 2004; accepted 5 October 2004; published 9 December 2004.
}

[1] We examined the response of terrestrial carbon fluxes to climate variability induced by the El Niño-Southern Oscillation (ENSO). We estimated global net primary production (NPP) from 1982 to 1999 using a light use efficiency model driven by satellitederived canopy parameters from the Advanced Very High Resolution Radiometer and climate data from the National Centers for Environmental Prediction/National Center for Atmospheric Research reanalysis project. We estimated a summed heterotrophic respiration and fire carbon flux as the residual between NPP and the terrestrial net carbon flux inferred from an atmospheric inversion model, excluding the impacts of land use change. We propose that for global applications this approach may be more robust than traditional, biophysically based approaches of simulating heterotrophic respiration. NPP interannual variability was significantly related to ENSO, particularly at lower latitudes $\left(22.5^{\circ} \mathrm{N}-22.5^{\circ} \mathrm{S}\right)$ but was weakly related to global temperature. Global heterotrophic respiration and fire carbon fluxes were strongly correlated with global temperature $\left(7.9 \mathrm{pgC} /{ }^{\circ} \mathrm{C}\right)$. Our results confirm the dependence of global heterotrophic respiration and fire carbon fluxes on interannual temperature variability and strongly suggest that ENSOmediated NPP variability influences the atmospheric $\mathrm{CO}_{2}$ growth rate. INDEX TERMS: 0315 Atmospheric Composition and Structure: Biosphere/atmosphere interactions; 1615 Global Change: Biogeochemical processes (4805); 1640 Global Change: Remote sensing; 1620 Global Change: Climate dynamics (3309); 1833 Hydrology: Hydroclimatology; KEYWORDS: carbon cycling, ENSO, net primary production

Citation: Hashimoto, H., R. R. Nemani, M. A. White, W. M. Jolly, S. C. Piper, C. D. Keeling, R. B. Myneni, and S. W. Running (2004), El Niño-Southern Oscillation-induced variability in terrestrial carbon cycling, J. Geophys. Res., 109, D23110, doi:10.1029/2004JD004959.

\section{Introduction}

[2] The willingness of world governments to limit the emission of greenhouse gasses is partially limited by scientific uncertainty regarding the interactions among terrestrial ecosystems, climate variability and trends, and atmospheric $\mathrm{CO}_{2}$ concentrations. For example, coupled climate/carbon cycle models indicate positive feedbacks between respiration and climate change will occur in the 21 st century [Cox et al., 2000; Dufresne et al., 2002] but the magnitude of these responses is highly uncertain [Friedlingstein et al., 2003]. Developing a clear understanding of the relationship between past climate variability and ecosystem processes

\footnotetext{
${ }^{1}$ Graduate School of Agricultural and Life Sciences, University of Tokyo, Tokyo, Japan.

${ }^{2}$ NASA Ames Research Center, Moffett Field, California, USA.

${ }^{3}$ Department of Aquatic, Watershed, and Earth Resources, Utah State University, Logan, Utah, USA.

${ }^{4}$ Numerical Terradynamic Simulation Group (NTSG), School of Forestry, University of Montana, Missoula, Montana, USA.

${ }^{5}$ Scripps Institution of Oceanography, La Jolla, California, USA.

${ }^{6}$ Department of Geography, Boston University, Boston, Massachusetts, USA.
}

Copyright 2004 by the American Geophysical Union. 0148-0227/04/2004JD004959\$09.00 will provide an opportunity to increase our confidence in future carbon cycling-climate scenarios [Reichenau and Esser, 2003; Schaefer et al., 2002; Potter et al., 2003].

[3] In addition to understanding the impacts of long-term secular climate changes, it is crucial to analyze the importance of cyclic climatic phenomenon for interannual variability in carbon cycle processes. In particular, because of pervasive teleconnections, the El Niño-Southern Oscillation (ENSO) is likely to have a strong impact on the global carbon balance [Foley et al., 2002; Botta et al., 2002; Potter et al., 2003]. In spite of some controversy [Cobb et al., 2003], evidence suggests that the frequency of warm phase (El Niño) ENSO events has increased since the 1980s [Trenberth and Hoar, 1997], implying that a similar systematic shift in the global carbon balance may have occurred simultaneously.

[4] The response of the global carbon cycle to such variations in ENSO strength can be inferred from atmospheric $\mathrm{CO}_{2}$ observations. Bacastow [1976] first showed significant correlation between the Southern Oscillation Index (SOI) and $\mathrm{CO}_{2}$ growth rates at Mauna Loa and the South Pole. Using an expanding network of atmospheric observation sites [Conway et al., 1994], scientists developed a consensus regarding the response of terrestrial ecosystems to ENSO events [Battle et al., 2000; Le Quéré et al., 2003]: 
during El Niño, carbon sequestration is reduced on land and increased in oceans; the reverse is true in the La Niña phase. Since the carbon cycle reaction to ENSO events is stronger in terrestrial systems than in oceans, El Niños result in a net global carbon release to the atmosphere. Although the exact magnitude is uncertain, evidence from atmospheric inversion and ocean models [Le Quéré et al., 2003] indicates that the interannual variation of terrestrial ecosystem carbon processes is in phase with ENSO events.

[5] Global carbon cycle models incorporating climate response functions are used to clarify the mechanisms behind these responses. In the terrestrial portion of these models, net $\mathrm{CO}_{2}$ uptake is the difference between net primary production (NPP) and heterotrophic respiration (HR), each of which is a function of climatic and vegetation processes and properties. Using a simple empirical model and variations in temperature and precipitation, Dai and Fung [1993] explained at least half of the missing sink for 1950-1984. This approach, however, provides little mechanistic understanding of the processes controlling carbon sequestration or emission. In process models, which can provide a mechanistic understanding of ecosystems responses, it is possible to derive correct net $\mathrm{CO}_{2}$ from errors in both NPP and HR [Running and Hunt, 1993].

[6] An alternative approach, pursued here, is to employ a quasi-mechanistic model for NPP and to obtain heterotrophic respiration as the residual between NPP and inverse estimates of net carbon balance. Using this approach, our goal is to assess the spatiotemporal response of NPP and heterotrophic respiration to climatic variability, especially ENSO strength.

\section{Data and Methods}

[7] We calculated monthly global $0.5^{\circ} \mathrm{NPP}$ from 1982 to $1999\left(0.5^{\circ}\right.$ is a common resolution for global carbon models [Cramer et al., 1999]) using the light use efficiency (LUE) approach [Monteith, 1972]. In our model, Gross Primary Production (GPP) is calculated as

$$
G P P=\varepsilon * F P A R * P A R,
$$

where $\varepsilon$ is LUE $\left(\mathrm{g} \mathrm{MJ}^{-1}\right)$, PAR is photosynthetically active radiation (MJ), and FPAR is the fraction of PAR absorbed by plant canopies ( 0 to $100 \%$ ). Temperature and water constrain photosynthesis as follows:

$$
\varepsilon=\varepsilon_{\max } * W(V P D) * T(T \min ),
$$

where $\varepsilon_{\max }$ is the maximum biome-specific LUE, $W$ is a limitation factor that is a function of Vapor Pressure Deficit (VPD, Pa), and $T$ is a limiting factor of minimum temperature (Tmin). We used an 11-biome landcover map based on work by DeFries and Townshend [1994] and a look-up table optimized from the Biome-BGC model [Running and Hunt, 1993; Thornton, 1998; White et al., 2000] to define the global distribution of $\varepsilon_{\max }, W$ and $T$. In the optimization scheme, VPD acts as a proxy for the overall plant water stress including rainfall deficits as well as low humidity. As a consequence, our GPP model does not use precipitation data.

[8] We predicted autotrophic respiration by first calculating various ecosystem carbon pool sizes using biome- specific allometric equations based on leaf area index (LAI) and subsequently by applying exponential temperature functions. We then calculated NPP as the difference between GPP and autotrophic respiration (equation (3))

$$
N P P=G P P-R_{\text {auto }}(L A I, T),
$$

where $R_{\text {auto }}$ is the autotrophic respiration. Details of the NPP calculation algorithm are available in work by Running et al. [2000] and Nemani et al. [2003].

[9] LAI and FPAR data sets used in this study were generated using a 3-D radiative transfer model [Myneni et al., 1997] in conjunction with monthly AVHRR (Advanced Very High Resolution Radiometer) Normalized Difference Vegetation Index (NDVI). For an extended discussion of the data sets and methods, please see Nemani et al. [2003, supplement].

[10] We used the National Centers for Environmental Prediction/National Center for Atmospheric Research Reanalysis data (hereafter referred to as reanalysis) [Kalnay et al., 1996; Kistler et al., 2001] for climatic inputs. The reanalysis uses a T62/28-level spectral model in the assimilation system. Although the reanalysis contains systematic spatiotemporal biases in many variables caused by cloud/ moisture parameterization, prescribed surface parameterization, complex topography, etc., it is considered robust enough for use in studies investigating interannual ENSO variation [Mo and Higgins, 1996; Janowiak et al., 1998; Yang et al., 1999; Ribera and Mann, 2002]. Extensive verification of reanalysis data was conducted using ancillary data sets of solar radiation and air temperature, two of the main variables in our NPP modeling, and reported by Nemani et al. [2003, supplement].

[11] Accurate modeling of the spatiotemporal distribution of HR is extremely difficult because of at least three reasons. First, soil carbon pools can only be measured at specific sites, while aboveground carbon can be estimated from satellite data. For example, LAI or above ground biomass can be estimated from satellites using radiative transfer models. Next, temperature (often assessed using a $\mathrm{Q}_{10}$ or other temperature-based approach [Lloyd and Taylor, 1994]), precipitation [Raich and Schlesinger, 1992], GPP [Janssens et al., 2001], and disturbance history [Wardle et al., 2003] all influence HR, but there is still considerable uncertainty in spatially explicit estimates of these variables. Knorr [2000] attributes the uncertainty of the interannual variability of soil respiration to $\mathrm{Q}_{10}$ and litter turn over time, and both of them are highly variable in space. Finally, process-based models often assume that HR is in equilibrium with NPP over some period, but the selection of the period is arbitrary.

[12] Instead of attempting an explicit calculation, we used a three-step residual approach to estimate global HR. First, we obtained the net land $\mathrm{CO}_{2}$ balance estimated from the Scripps Oceanography Institute inversion model (based on inverse techniques using a double deconvolution of $\mathrm{CO}_{2}$ and $\delta^{13} \mathrm{C}$ from nine stations in the Pacific Ocean basin [Keeling et al., 2001; Le Quéré et al., 2003]). Since a $\mathrm{CO}_{2}$ observation network sufficient to obtain a robust time series of regional carbon uptakes is lacking [Bousquet et al., 2000], this estimate is valid for global fluxes only. Second, we subtracted this net land $\mathrm{CO}_{2}$ balance from our simulated 
NPP, yielding our initial estimate of global HR. Third, we subtracted land use carbon estimates [Houghton and Hackler, 2002] because the net land $\mathrm{CO}_{2}$ signal includes carbon emissions from land use change and we were attempting to isolate HR. This yielded a land use corrected value for global $\mathrm{HR}$.

[13] Although biomass burning contributes to the interannual variability of carbon release [Langenfelds et al., 2001; Page et al., 2002; van der Werf et al., 2004], atmospheric observations of carbon emissions from global fires are not available for the 1980s. Consequently we did not subtract fire carbon emissions and our carbon release term represents the sum of HR and carbon released from fires.

[14] Using this model construct, we conducted four separate analyses. First, in order to separate the influence of vegetation structure and phenology versus climate factors, we conducted the following three NPP simulations: (1) changing vegetation (FPAR and LAI) and climate (VPD, temperature and radiation); (2) changing vegetation and constant climate; and (3) constant vegetation and changing climate.

[15] Second, we analyzed NPP anomaly patterns for El Niño periods. Trenberth [1997] defined an El Niño when 5 -month running means of sea surface temperature anomalies in the El Niño 3.4 region $\left(5^{\circ} \mathrm{N}-5^{\circ} \mathrm{N}, 120^{\circ} \mathrm{W}-170^{\circ} \mathrm{W}\right)$ exceeded $0.4^{\circ} \mathrm{C}$ for 6 months or more; by this method, El Niños occurred in 1982-1983, 1986-1988, 199119-92, 1993, 1994-1995, and 1997-1998. Because of their unusual nature and the 1991 Pinatubo eruption, we did not consider the 1991 to $1995 \mathrm{El} \mathrm{Niños.} \mathrm{In} \mathrm{order} \mathrm{to} \mathrm{isolate} \mathrm{the} \mathrm{lagged}$ response of NPP to ENSO, as measured by the Multivariate ENSO Index (MEI [Wolter and Timlin, 1998]), we detrended monthly NPP and then created averaged monthly NPP anomalies for low $\left(22.5^{\circ} \mathrm{N}-22.5^{\circ} \mathrm{S}\right)$, mid $\left(47.5^{\circ} \mathrm{N}-\right.$ $\left.22.5^{\circ} \mathrm{N}\right)$, and high $\left(90^{\circ} \mathrm{N}-47.5^{\circ} \mathrm{N}\right)$ latitude regions. On the basis of these results, we then conducted a climate anomaly analysis for the latitudinal region contributing most to global NPP anomalies.

[16] Third, we assessed the detrended global response of climatic variables (temperature, VPD, and radiation) and NPP to 6-month lagged MEI. In reality, the time lag is variable and should be short in regions close to the equatorial Pacific where MEI is calculated. However, we used a fixed 6-month lag for simplicity, and the difference of the regression result between no time lag and 6-month lag was small (not shown here). We removed seasonal autocorrelation with a 12-month running average, although removing autocorrelation can remove lowfrequency correlations [Potter et al., 2003], and then used linear regressions with a 2-tailed $t$ test of significance for each pixel. There were 166 degrees of freedom [(18 - 1(running average) -3 (Pinatubo effected year) $) *$ 12 (monthly interval) - 2 (two-tailed test)].

[17] Fourth, we analyzed trends in the interannual variability of carbon release (HR plus fire), NPP, and net carbon balance in response to ENSO cycles. We finally assessed the relationship between global temperatures and these global NPP and carbon release anomalies. Here we used the highly quality controlled, updated, and cited [Intergovernmental Panel on Climate Change, 2001] global temperature data from Jones et al. [2001]. These data, which include both land and ocean, are strongly in phase with land temperature

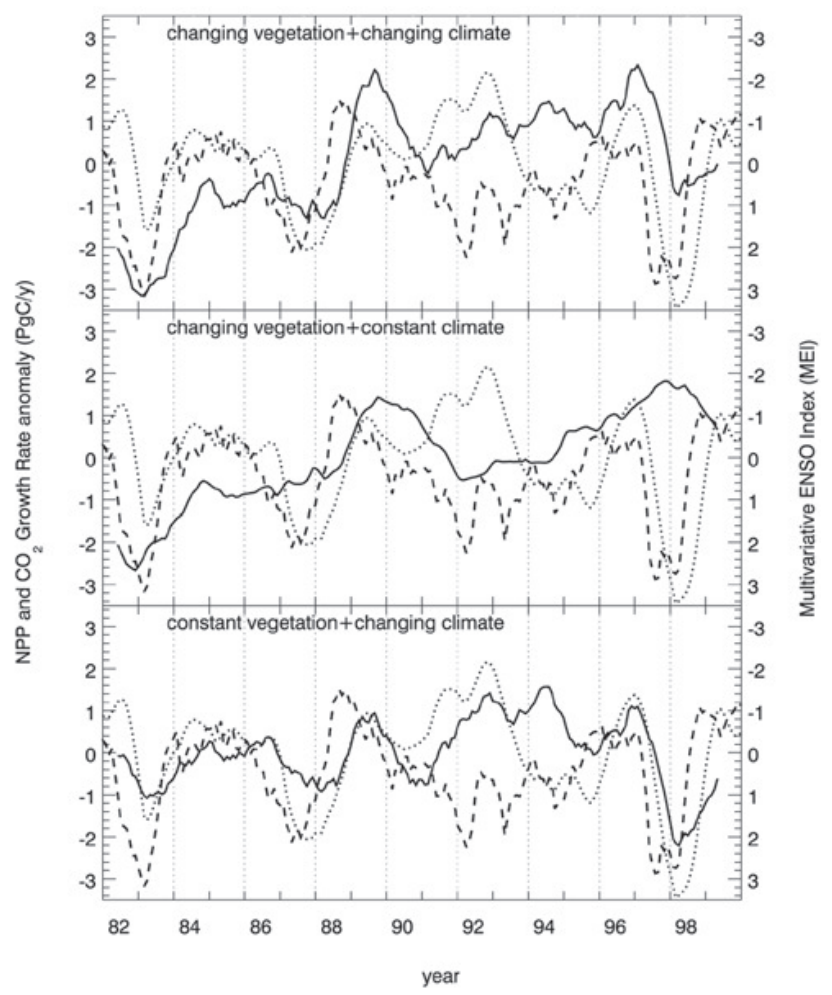

Figure 1. Time series of global NPP anomaly (solid line), global $\mathrm{CO}_{2}$ growth rate anomaly (dashed line, inverted scale), and MEI (dotted line). High MEI represents ENSO warm phase. NPP anomaly is calculated from a 12-month running total of monthly global NPP.

and thus provide a useful and independent alternative to further use of the reanalysis data.

\section{Results and Discussion}

\subsection{Interannual Variation of NPP, ENSO,} and $\mathrm{CO}_{2}$ Growth Rate

[18] In our simulations, the 1982 to 1999 interannual variability of terrestrial NPP was predominantly determined by climatic variations, not vegetation dynamics (Figure 1). Similarity between the cycles of MEI and NPP was highest in the changing vegetation + changing climate and constant vegetation + changing climate simulations. NPP variation in the changing vegetation + constant climate simulation, wherein the effects of variable FPAR and LAI were disconnected from simultaneous climate variability, was dramatically different, with lower interannual variability and a more apparent long-term trend of increasing NPP.

[19] The strong relationship between the $\mathrm{CO}_{2}$ growth rate and NPP variations in changing vegetation + changing climate and constant vegetation + changing climate experiments, suggests a coherence between factors that regulate net ecosystem exchange (NEE) and NPP. There is a discrepancy between the $\mathrm{MEI}$ and the $\mathrm{CO}_{2}$ growth rate from 1991 to 1993 when climatic effects from the Mount Pinatubo volcanic eruption overwhelmed the ENSO perturbation [Jones and Cox, 2001; Reichenau and Esser, 2003]. 


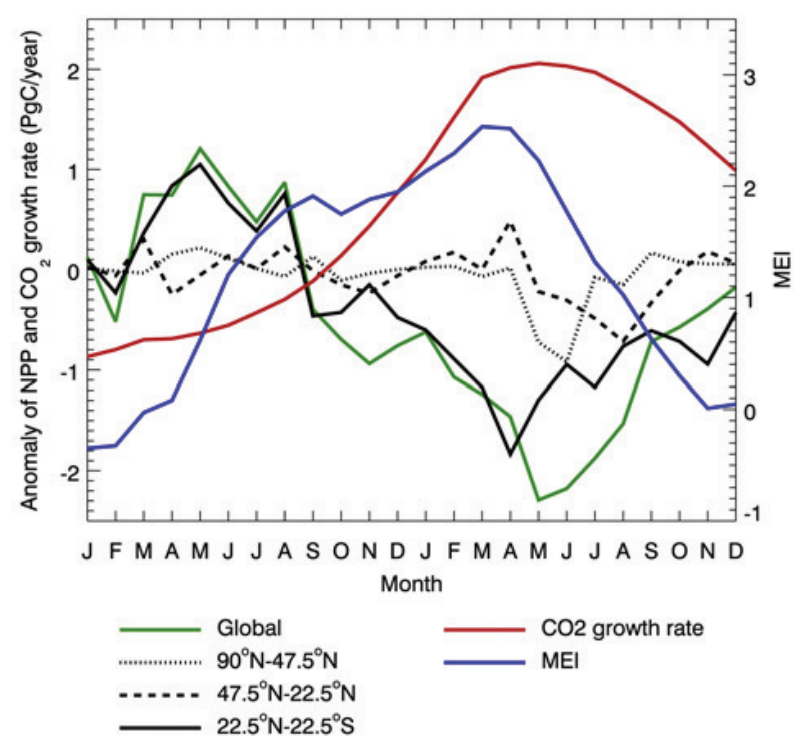

Figure 2. Summary of NPP and atmospheric $\mathrm{CO}_{2}$ responses during El Niño years (1982-1983, 1986-1987, and 1997-1998). NPP anomalies are shown for each latitudinal band (dotted black line, $90^{\circ} \mathrm{N}-47.5^{\circ} \mathrm{N}$; dashed black line, $47.5^{\circ} \mathrm{N}-22.5^{\circ} \mathrm{N}$; and solid black line, $22.5^{\circ} \mathrm{N}-$ $22.5^{\circ} \mathrm{S}$ ) and globally (green line). Red line is $\mathrm{CO}_{2}$ growth rate anomaly; blue line is MEI.

\subsection{Temporal Response of NPP to ENSO}

[20] Our analysis of the three El Niño periods suggests that global NPP began to decline about 6 months after the initiation of increasing MEI and that these global NPP decreases then affected the global $\mathrm{CO}_{2}$ growth rate (Figure 2). Initiation of the secular decrease in the global NPP anomaly occurred in August/September, about 6 months after the initial MEI increase in February/March. The $\mathrm{CO}_{2}$ growth rate anomaly (calculated by subtracting annual values from the mean $\mathrm{CO}_{2}$ growth rate from 1982 to 1999 (1.55 ppm/yr) and multiplying $2.1 \mathrm{pgC} / \mathrm{ppm})$ began a sharp increase around September of the first year and peaked during the boreal summer of the second year. The maximum first derivative of the $\mathrm{CO}_{2}$ growth rate was essentially concurrent with the linearly decreasing global NPP (August/ September of first year to May/June of second year). As other factors such as HR, biomass burning, fossil fuel production, land cover change, and oceanic uptake all affect the $\mathrm{CO}_{2}$ growth rate, it is difficult to compare directly global NPP and $\mathrm{CO}_{2}$ growth rate. Although Rayner et al. [1999] suggested that oceanic carbon uptake causes the negative first-year $\mathrm{CO}_{2}$ growth rate anomaly our results imply that global NPP also contributes to negative $\mathrm{CO}_{2}$ growth rate in much of the first year of El Niño events and higher rates thereafter.

[21] Furthermore, it appears that low-latitude tropical regions $\left(22.5^{\circ} \mathrm{N}-22.5^{\circ} \mathrm{S}\right)$ were largely responsible for these effects. From January through September of the first year of El Niños, the NPP anomaly of low-latitude regions was virtually identical to the global anomaly; patterns for the duration of the El Niño were also similar. With the exception of a moderate decline in May and June of the second year, the NPP anomaly of high-latitude regions $\left(90^{\circ} \mathrm{N}-\right.$ $\left.47.5^{\circ} \mathrm{N}\right)$ was essentially flat. Middle latitude regions $\left(47.5^{\circ} \mathrm{N}-22.5^{\circ} \mathrm{N}\right)$ were similar to high-latitude regions and showed a minimum NPP anomaly in August of the second year. Vegetation activity in middle and high-latitude regions peaks in boreal summer, producing a maximal carbon release lagging the low-latitude response. The minimum of the global NPP anomaly therefore occurred during early summer of the second year.
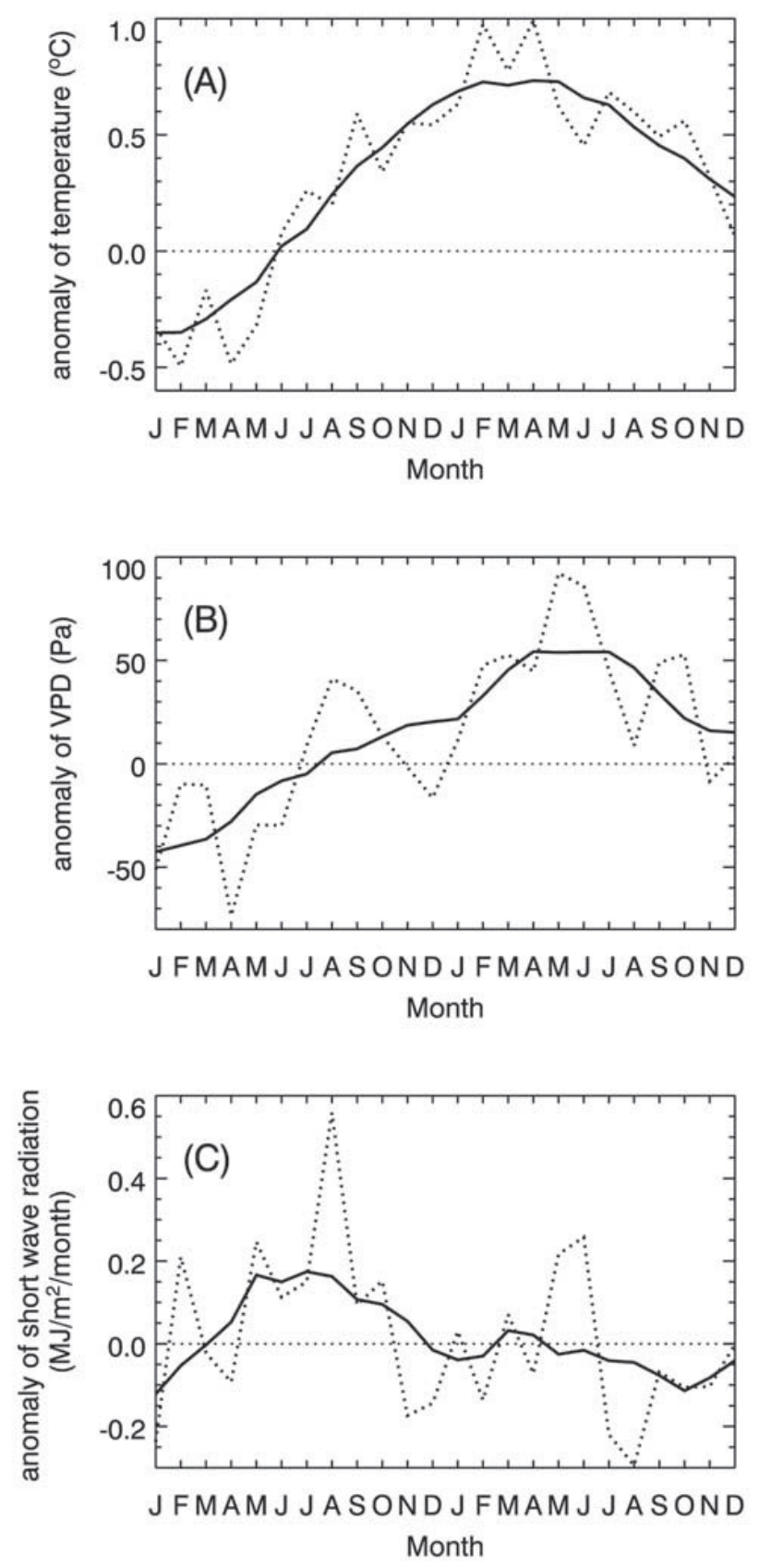

Figure 3. Anomalies of (a) temperature, (b) VPD, and (c) short-wave radiation over tropical regions during El Niño years $(1982-1983,1986-1987$, and 1997-1998). Solid line represents a running mean of monthly values shown as dotted line. 


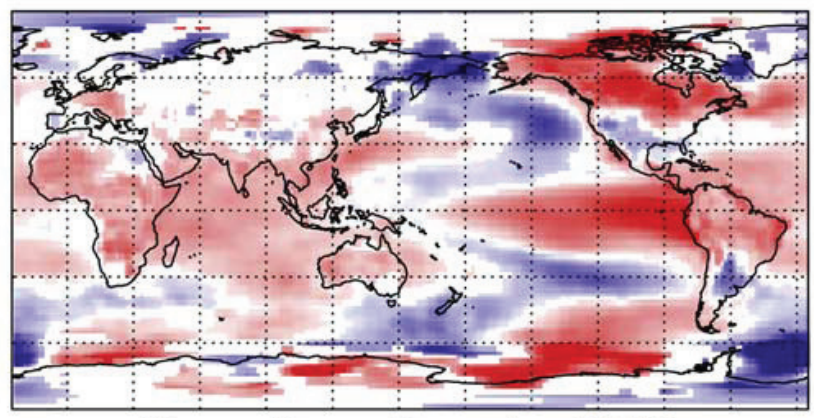

Change of Average Temperature $\left({ }^{\circ} \mathrm{C} / \mathrm{MEI}\right)$
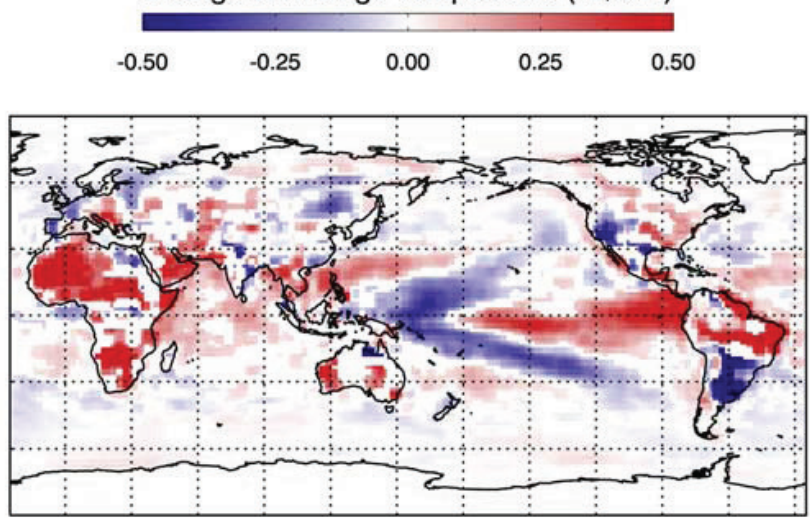

Change of VPD (Pa/MEI)
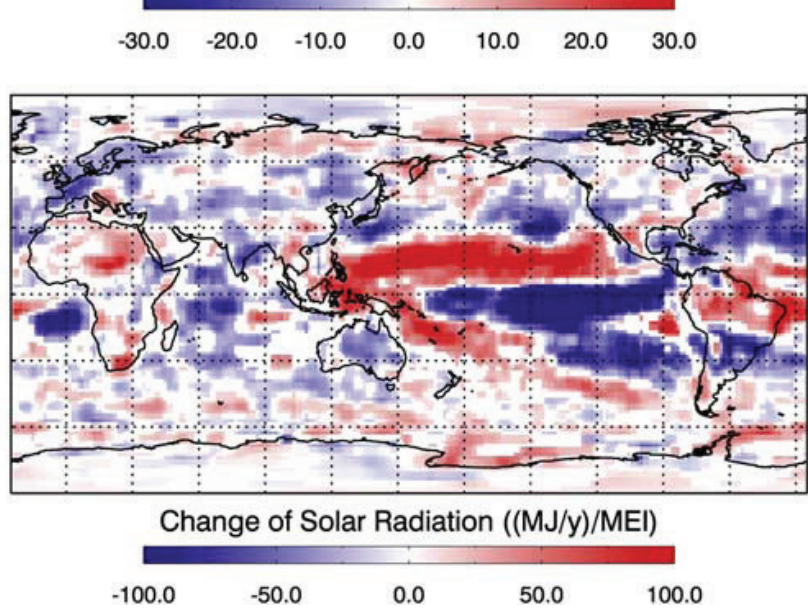

Figure 4. Six-month lagged linear regressions of (top) temperature, (middle) VPD, and (bottom) short-wave radiation versus MEI. Values from 1991 to 1993 period are excluded. Data that have $95 \%$ significance level are shown.

[22] Our results agree with other process-based model studies showing that the interannual variations in $\mathrm{CO}_{2}$ growth rate are largely regulated by the interannual variations of NEE in the tropics [Kaduk and Heimann, 1994; Kindermann et al., 1996; Gérard et al., 1999]. Inverse models of $\mathrm{CO}_{2}$ measurements also show similar results [Bousquet et al., 2000].

[23] On the basis of its role in explaining the global El Niño-NPP signal (Figure 2), we investigated the climatic component of tropical El Niños (Figure 3). While the interpretation of these results is limited by the use of only three El Niño events, possible underestimation of fire effects
[Reichenau and Esser, 2003], and uncertainty in the interannual variability of atmospheric transport [Dargaville et al., 2000], a coherent climatic pattern is evident. The temperature anomaly was negative from January to June of the first year, and was greater than $0.5^{\circ} \mathrm{C}$ for most of the second year. The VPD anomaly was also negative before July of the first year, and then became positive with the exception of drops around December of both years. The anomaly of short-wave radiation was irregular but tended to be positive before October of the first year and negative thereafter. In summary, the climate variables show two patterns: (1) high NPP in the first year of El Niños occurred in conjunction with cooler temperatures, low VPD, and high radiation, and (2) low NPP during the second year occurred in conjunction with warm temperatures, high VPD, and average or low radiation.

\subsection{Spatial Response of Climate and NPP to ENSO}

[24] Figure 4 shows the spatial patterns of regressions between climatic variation (temperature, VPD and shortwave radiation) and 6-month lagged MEI. In our study, as in others [Ropelewski and Halpert, 1987; Hoerling and Kumar, 2003], global climate exhibited coherent spatial responses to MEI strength. Generally, tropical regions and northern North America warmed with increasing MEI. On the contrary, southwestern North America, northeast Asia, and southern South America cooled in the warm phase. In the warm phase, VPD increased in southern and northwestern Africa and large portions of the Amazon basin but decreased in southwestern North America, Argentina, the Middle East, and Central Africa. Short-wave radiation had a more extensive negative relationship with MEI but increased in the Amazon and south central North America during warm phases.

[25] MEI variation also strongly impacted global carbon cycle (Figure 5). In most regions, increasing MEI was negatively correlated with NPP. This pattern was especially strong in northern South America, Africa below the Sahel, and eastern North America. The general tendency of NPP to decrease in the warm phase reduced global NPP by more than $2 \mathrm{pgC} / \mathrm{yr}$ in 1997/1998 (Figure 1). Only northwestern

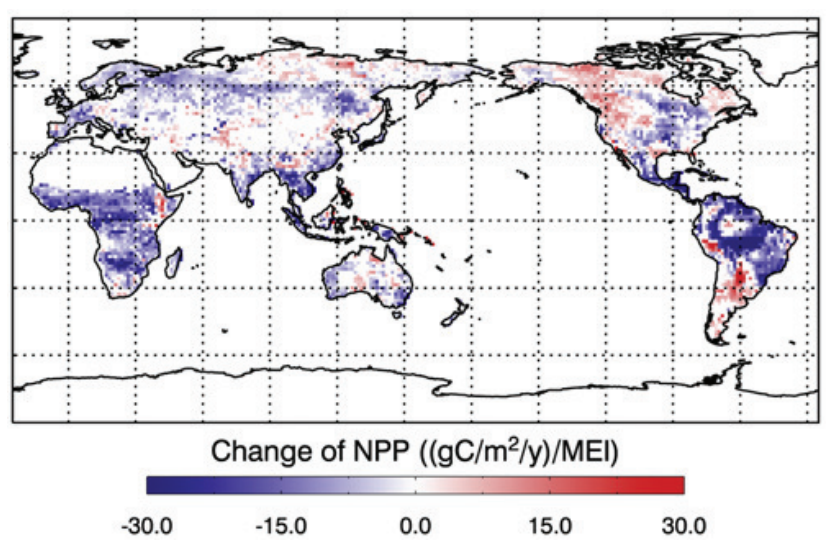

Figure 5. Six-month lagged linear regressions of NPP and MEI (1991 to 1993 excluded) showing the global impacts of ENSO on terrestrial NPP. Data that have 95\% significance level are shown. 


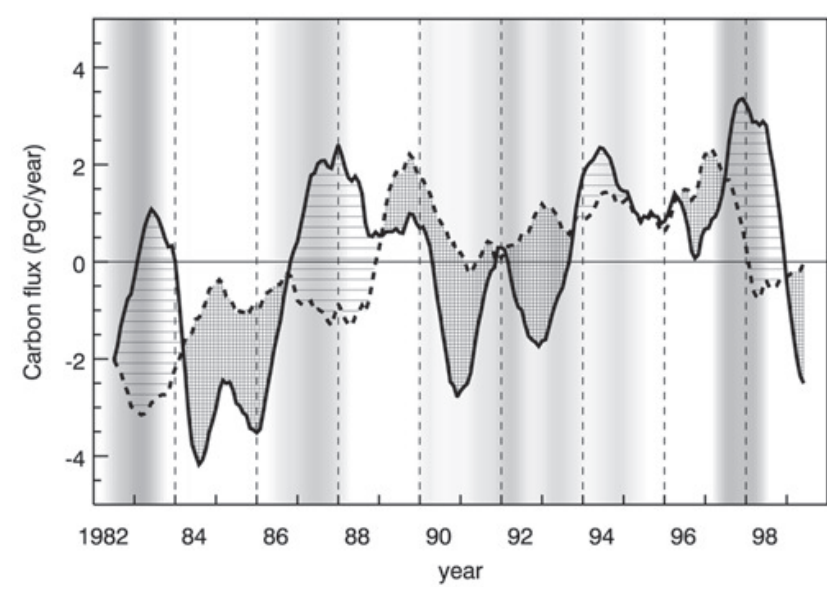

Figure 6. Anomaly of global NPP (dashed line) and carbon release (sum of HR and carbon released from fires, solid line) from 1982 to 1999 . The difference between NPP and HR is carbon balance from Keeling et al. [2001]. Horizontal lines show net carbon release, and checkered areas show uptake. MEI is shown in gray scale, where darker shades represent higher MEI (warm phase).

North America and Argentina had strong positive relationships with MEI. These warm phase NPP increases were related to warmer temperatures in northwestern North America and cooler temperatures and reduced VPD in Argentina.

[26] Jones et al. [2001] and Schaefer et al. [2002] conducted similar analyses for GPP (not for NPP as in this study). As for this study, these authors also found warm phase decreases GPP in India and Australia due to drought and increases GPP in northwestern North America due to favorable moisture regimes. However, we found a decrease in NPP over western Africa and parts of Amazonia while others found an increase [Jones et al., 2001] or no change [Schaefer et al., 2002]. These differences may be a result of different climate data sets, NCEP/NCAR reanalysis data (this study), HadCM3LC [Jones et al., 2001] and ECMWF reanalysis data [Schaefer et al., 2002].

[27] In the northern Amazon basin, our results showed no significant change while Jones et al. [2001] showed a strong decrease. Climate data in all cases showed drought in the warm phase, so the different NPP response is from model sensitivity to drought. These model-dependent responses were reported especially in the northwestern Amazon basin. For example, Tian et al. [1998] showed no significant change in the northwestern part of Amazon basin, but Foley et al. [2002] showed a decrease. Differences in model parameterization of rooting depths appear to be one of the main drivers leading to different NPP responses [Nepstad et al., 1994].

\subsection{Net Carbon Balance From Atmospheric Inversion}

[28] Figure 6 shows the interannual variability of NPP and HR. Large global net carbon releases occurred during or soon after strong El Niños (1982-1983, 1986-1987, and 1997-1998) while major net uptake occurred during periods of low MEI or La Niña periods. Some process-based studies showed that HR anomalies are smaller than NPP anomalies [Kindermann et al., 1996; Gérard et al., 1999], but other studies [Knorr, 2000; Cao et al., 2002] showed almost similar magnitudes. Whether NPP anomalies exceed $\mathrm{HR}$ anomalies is largely dependent on model parameterization (especially $\mathrm{Q}_{10}$ ) for process-based models. In our study, $\mathrm{NEE}$ anomalies were within $2 \mathrm{pgC} / \mathrm{yr}$, and were slightly larger than NPP.

[29] We tested, using a two-tailed test, the significance of the trends in NPP, HR and net carbon balance from the deconvolution. There was no statistically significant trend $(p>0.1)$ in HR, whereas NPP increased significantly $(p<$ $0.05)$. The carbon balance from the deconvolution showed a moderate trend $(0.05<\mathrm{p}<0.1)$ in carbon uptake. If we included a $\mathrm{CO}_{2}$ fertilization effect in our simulations the NPP (HR) trend would increase (decrease). Therefore it appears that there can be no trend in HR, and the moderate
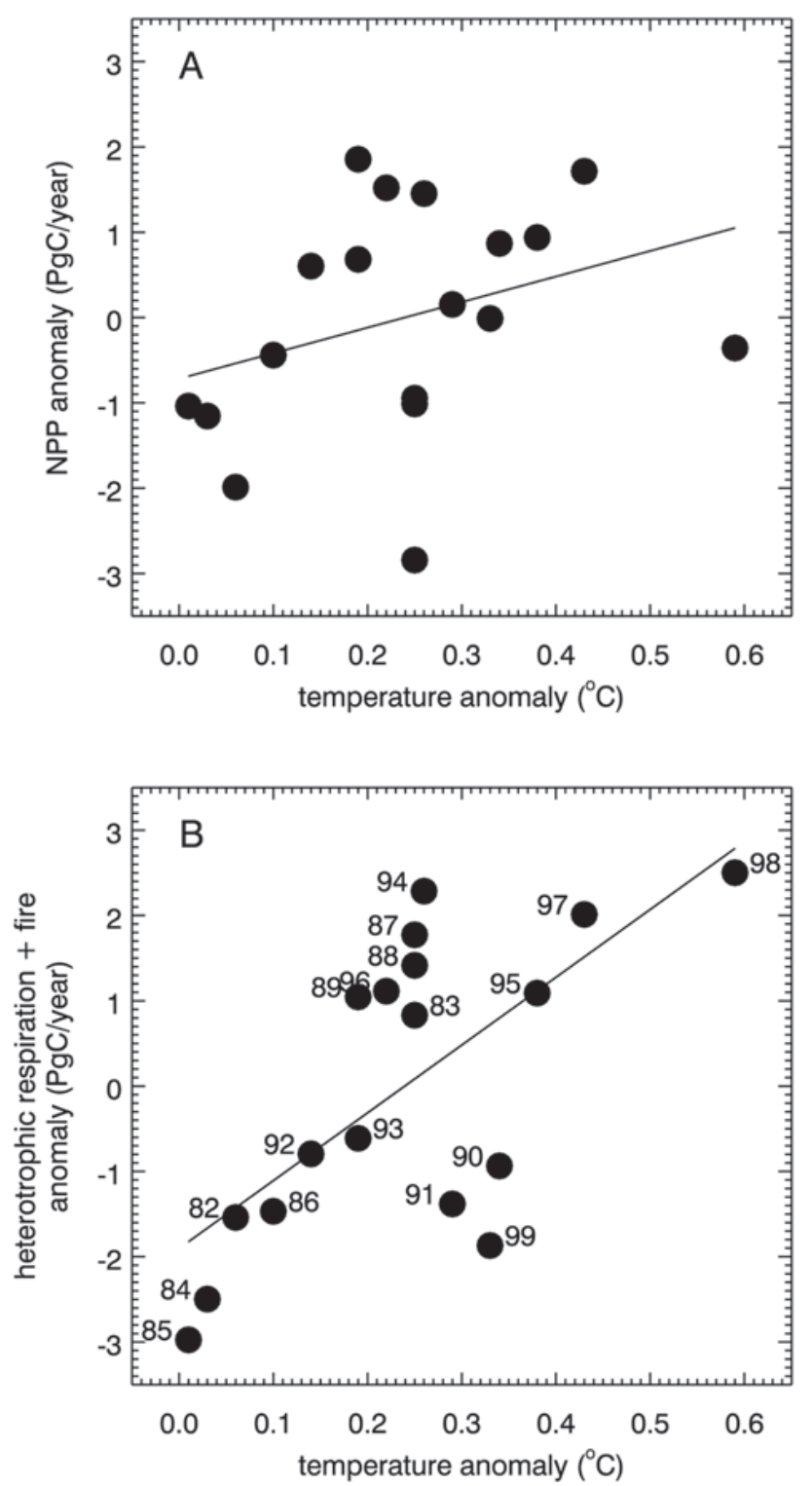

Figure 7. Correlation between global temperature anomalies [Jones et al., 2001] and anomalies in (a) NPP and (b) HR plus fire. Numbers in Figure $7 \mathrm{~b}$ indicate the years (1982-1999). 
trend in carbon uptake by land can be attributed only to increasing NPP. Previous modeling studies estimated a significant increasing trend in HR in the 1980s and 1990s [Cao et al., 2002], but acclimation may negate the increase trend. [Luo et al., 2001; Cao et al., 2002].

[30] We correlated the NPP and HR with anomaly of the climate components to explain which component dominates in global carbon cycle (Figure 7). Anomalies of carbon release had a positive correlation with global temperature $(\mathrm{r}=0.67, \mathrm{p}<0.005)$ while NPP anomalies had no correlation with global temperature $(r=0.33, p>0.1)$. Using different methods, others [e.g., Raich et al., 2002] have shown a similar temperature dependency of HR. We also checked the relationship between carbon release and VPD, precipitation, and radiation but found no meaningful relationship.

[31] El Niños are associated with extensive biomass burning and subsequent large pulses of carbon release. For example, Langenfelds et al. [2002] estimated carbon release by biomass burning of 0.6-3.5 pgC/yr in 1994/1995 and 0.8-3.7 pgC/yr in 1997/1998. Van der Werf et al. [2004] estimated a yearly anomaly of $0.59 \mathrm{pgC} / \mathrm{yr}$ for 1997 and $1.17 \mathrm{pgC} / \mathrm{yr}$ for 1998. Thus, while the slope of the regression in Figure $7 \mathrm{~b}$ is $7.9 \mathrm{pgC} /$ degree, the regression of HR without fire would be smaller. Overall, our results indicate that global HR, but not NPP, is strongly influenced by temperature variability.

\section{Conclusion}

[32] A large suite of ENSO-influenced climate variables strongly influences interannual variability in NPP [Nemani et al., 2003]. There is considerable spatial variability in these controls and consequently in the magnitude and direction of El Niño impacts on terrestrial NPP. On the other hand, heterotrophic respiration is primarily sensitive to temperature. We observed that the global $\mathrm{CO}_{2}$ growth rate appears to be highly responsive to global and especially tropical NPP, which in turn has a 6-month lagged relationship with MEI. A number of factors besides interannual climate variability affect global carbon cycling including decadal/century-scale climate oscillations [Botta et al., 2002], land use/land cover changes and socioeconomics and technology. A better understanding of their relative contributions to the ever-increasing atmospheric $\mathrm{CO}_{2}$ concentrations is clearly needed.

[33] Acknowledgments. This research was supported by a doctoral fellowship to HH from the Japan Society for the Promotion of Science (JSPS). Funding from NASA Earth Science Enterprise programs supported RRN, MAW, SWR, RBM, CDK, and SCP. We thank the two anonymous reviewers for their constructive comments on the original manuscript.

\section{References}

Bacastow, R. B. (1976), Modulation of atmospheric carbon dioxide by the Southern Oscillation, Nature, 261, 116-118.

Battle, M., M. L. Bender, P. P. Tans, J. W. C. White, J. T. Ellis, T. Conway, and R. J. Francey (2000), Global carbon sinks and their variability inferred from atmospheric $\mathrm{O}_{2}$ and $\delta^{13} \mathrm{C}$, Science, 287, 2467-2470.

Botta, A., N. Ramankutty, and J. A. Foley (2002), Long-term variations of climate and carbon fluxes over the Amazon basin, Geophys. Res. Lett., 29(9), 1319, doi:10.1029/2001GL013607.

Bousquet, P., P. Peylin, P. Ciais, C. Le Quéré, P. Friedlingstein, and P. P. Tans (2000), Regional change in carbon dioxide fluxes of land and oceans since 1980, Science, 290, 1342-1346.
Cao, M., S. D. Prince, and H. H. Shugart (2002), Increasing terrestrial carbon uptake from the 1980 s to the 1990 s with changes in climate and atmospheric $\mathrm{CO}_{2}$, Global Biogeochem. Cycles, 16(4), 1069, doi:10.1029/2001GB001553.

Cobb, K. M., C. D. Charles, H. Cheng, and R. L. Edwards (2003), El Niño/ Southern Oscillation and tropical Pacific climate during the last millennium, Nature, 424, 271-276.

Conway, T. J., P. P. Tans, L. S. Waterman, W. D. R. K.Thoning Kitzis, K. A. Masarie, and N. Zhang (1994), Evidence for interannual variability of the carbon cycle from the National Oceanic and Atmospheric Administration/Climate Monitoring Diagnostics Laboratory Global Air Sampling Network, J. Geophys. Res., 99(D11), 831-855.

Cox, P. M., R. A. Betts, C. D. Jones, S. A. Spall, and I. J. Totterdell (2000), Acceleration of global warming due to carbon-cycle feedbacks in a coupled climate model, Nature, 408, 184-187.

Cramer, W., D. W. Kicklighter, A. Bondeau, B. Moore III, G. Churkina, B. Nermy, A. Ruimy, A. L. Schloss, and the participants of the Potsdam NPP Model Intercomparison (1999), Comparing global models of terrestrial net primary productivity (NPP): Overview and key results, Global Change biol., 5, suppl. 1, 1-15.

Dai, A., and I. Y. Fung (1993), Can climate variability contribute to the "missing" $\mathrm{CO}_{2}$ sink?, Global Biogeochem. Cycles, 7(3), 599-609.

Dargaville, R. J., R. M. Law, and F. Pribac (2000), Implications of interannual variability in atmospheric circulation on modeled $\mathrm{CO}_{2}$ concentrations and source estimates, Global Biogeochem. Cycles, 14(3), 931-943.

DeFries, R. S., and J. R. G. Townshend (1994), NDVI-derived land cover classification at a global scale, Int. J. Remote Sens., 15(17), 3567-3586. Dufresne, J. L., L. Fairhead, H. Le Treut, M. Berthelot, L. Bopp, P. Ciais, P. Friedlingstein, and P. Monfray (2002), On the magnitude of positive feedback between future climate change and the carbon cycle, Geophys. Res. Lett., 29(10), 1405, doi:10.1029/2001GL013777.

Foley, J. A., A. Botta, M. T. Coe, and M. H. Costa (2002), El NiñoSouthern Oscillation and the climate, ecosystems and rivers of Amazonia, Global Biogeochem. Cycles, 16(4), 1132, doi:10.1029/2002GB001872.

Friedlingstein, P., J. L. Dufresne, P. M. Cox, and P. Rayner (2003), How positive is the feedback between climate change and the carbon cycle?, Tellus, Ser. B, 55, 692-700.

Gérard, J. C., B. Nemry, L. M. François, and P. Warnant (1999), The interannual change of atmospheric $\mathrm{CO}_{2}$ : Contribution of subtropical ecosystems?, Geophys. Res. Lett., 26(2), 243-246.

Hoerling, M., and A. Kumar (2003), The perfect ocean for drought, Science, 299, 691-694.

Houghton, R. A., and J. L. Hackler (2002), Carbon flux to the atmosphere from land_use changes, in Trends: A Compendium of Data on Global Change, $\bar{C}$ arbon Dioxide Inf. Anal. Cent., Oak Ridge Natl. Lab., U.S. Dept. of Energy, Oak Ridge, Tenn., available at http://cdiac.esd.ornl.gov/ trends/landuse/houghton/houghton.html.

Intergovernmental Panel on Climate Change (2001), Climate Change 2001: The Scientific Basis, edited by J. T. Houghton et al., Cambridge Univ. Press, New York.

Janowiak, J. E., A. Gruber, C. R. Kondragunta, R. E. Livezey, and G. J. Huffman (1998), A comparison of the NCEP-NCAR reanalysis precipitation and the GPCP rain gauge-satellite combined dataset with observational error considerations, J. Clim., 11, 2960-2979.

Janssens, I. A., et al. (2001), Productivity overshadows temperature in determining soil and ecosystem respiration across European forests, Global Change Biol., 7, 269-278.

Jones, C. D., and P. M. Cox (2001), Modeling the volcanic signal in the atmospheric $\mathrm{CO}_{2}$, Global Biogeochem. Cycles, 15(2), 453-465.

Jones, C. D., M. Collins, P. M. Cox, and S. A. Spall (2001), The carbon cycle response to ENSO: A coupled climate-carbon cycles model study, J. Clim., 14, 4113-4129.

Kaduk, J., and M. Heimann (1994), The sensitivity of the Osnabrück biosphere model on the ENSO time scale, Ecol. Modell., 75-76, 239-256.

Kalnay, E., et al. (1996), The NCEP/NCAR 40-year reanalysis project, Bull. Am. Meteorol. Soc., 77(3), 437-471.

Keeling, C. D., S. C. Piper, R. B. Bacastow, M. Wahlen, T. P. Whorf, M. Heimann, and H. A. Meijer (2001), Exchanges of atmospheric $\mathrm{CO}_{2}$ and ${ }^{13} \mathrm{CO}_{2}$ with the terrestrial biosphere and oceans from 1978 to 2000 : I. Global aspects, SIO Ref. Ser. 00-06, Scripps Inst. of Oceanogr., La Jolla, Calif.

Kindermann, J., G. Würth, G. H. Kohlmaier, and F. W. Badeck (1996), Interannual variation of carbon exchange fluxes in terrestrial ecosystems, Global Biogeochem. Cycles, 10(4), 737-755.

Kistler, R., et al. (2001), The NCEP-NCAR 50-year reanalysis: Monthly means CD-ROM and documentation, Bull. Am. Meteorol. Soc., 82(2), $247-268$.

Knorr, W. (2000), Annual and interannual $\mathrm{CO}_{2}$ exchanges of the terrestrial biosphere: Process-band simulations and uncertainties, Global Ecol. Biogeogr., 9, 225-252. 
Langenfelds, R. L., R. J. Francey, B. C. Pak, L. P. Steele, J. Lloyd, C. M. Trudinger, and C. E. Allison (2002), Interannual growth rate variations of atmospheric $\mathrm{CO}_{2}$ and its $\delta^{13} \mathrm{C}, \mathrm{H}_{2}, \mathrm{CH}_{4}$, and $\mathrm{CO}$ between 1992 and 1999 linked to biomass burning, Global Biogeochem. Cycles, 16(3), 1048, doi:10.1029/2001GB001466.

Le Quéré, C., et al. (2003), Two decades of ocean $\mathrm{CO}_{2}$ sink and variability, Tellus, Ser. B, 55, 649-656.

Lloyd, J., and J. A. Taylor (1994), On the temperature dependence of soil respiration, Functional Ecol., 8, 315-323.

Luo, Y., S. Wan, D. Hui, and L. Wallace (2001), Acclimation of soil respiration to warming in a tall grass prairie, Nature, 413, 622-625.

Mo, K. C., and R. W. Higgins (1996), Large-scale atmospheric moisture transport as evaluated in the NCEP/NCAR and the NASA/DAO reanalyses, J. Clim., 9, 1531-1545.

Monteith, J. L. (1972), Solar radiation and productivity in tropical ecosystems, J. Appl. Ecol., 9, 747-766.

Myneni, R. B., R. R. Nemani, and S. W. Running (1997), Estimation of global leaf area index and absorbed PAR using radiative transfer models, IEEE Trans. Geosci. Remote Sens., 35(6), 1380-1393.

Nemani, R. R., C. D. Keeling, H. Hashimoto, W. M. Jolly, S. C. Piper, C. D. Tucker, R. B. Myneni, and S. W. Running (2003), Climate-driven increases in global terrestrial net primary production from 1982 to 1999, Science, 300, 1560-1563.

Nepstad, D. C., C. R. de Carvalho, E. A. Davidson, P. A. Lefebvre, G. H. Negreiros, E. D. da Silva, T. A. Stone, S. E. Trumbore, and S. Vieira (1994), The role of deep roots in the hydrological and carbon cycles of Amazonian forests and pastures, Nature, 372, 666-669.

Page, S. E., F. Siegert, J. O. Rieley, H.-D. V. Boehm, A. Jaya, and S. Limin (2002), The amount of carbon released from peat and forest fires in Indonesia during 1997, Nature, 420, 61-65.

Potter, C., S. Klooster, M. Steinbach, P. Tan, V. Kumar, S. Shekhar, R. Nemani, and R. Myneni (2003), Global teleconnections of climate to terrestrial carbon flux, J. Geophys. Res., 108(D17), 4556, doi:10.1029/ 2002JD002979.

Raich, J. W., and W. H. Schlesinger (1992), The global carbon dioxide flux in soil respiration and its relationship to vegetation and climate, Tellus, Ser. B, 44, 81-99.

Raich, J. W., C. S. Potter, and D. Bhagawati (2002), Interannual variability in global soil respiration, 1980-94, Global Change Biol., 8, $800-812$.

Rayner, P. J., R. M. Law, and R. Dargaville (1999), The relationship between tropical $\mathrm{CO}_{2}$ fluxes and the El Niño-Southern Oscillation, Geophys. Res. Lett., 26(4), 493-496.

Reichenau, T. G., and G. Esser (2003), Is interannual fluctuation of atmospheric $\mathrm{CO}_{2}$ dominated by combined effects of ENSO and volcanic aerosols?, Global Biogeochem. Cycles, 17(4), 1094, doi:10.1029/ 2002GB002025.

Ribera, P., and M. E. Mann (2002), Interannual variability in the NCEP reanalysis 1948-1999, Geophys. Res. Lett., 29(10), 1494, doi:10.1029/ 2001 GL013905.

Ropelewski, C. F., and M. S. Halpert (1987), Global and regional scale precipitations associated with the El Niño/Southern Oscillation, Mon. Weather Rev., 115, 1606-1626.
Running, S. W., and E. R. Hunt Jr. (1993), Generalization of a forest ecosystem process model for other biomes, BIOME-BGC, and an application for global scale models, in Scaling Physiological Processes Leaf to Globe, edited by J. R. Ehleringer and C. Field, pp. 141-158, Academic, San Diego, Calif.

Running, S. W., P. E. Thornton, R. R. Nemani, and J. M. Glassy (2000), Methods in Ecosystem Science, edited by O. Sala, R. Jackson, and H. Mooney, pp. 44-57, Springer-Verlag, New York.

Schaefer, K., A. S. Denning, N. Suits, J. Kaduk, I. Baker, S. Los, and L. Prihodko (2002), Effect of climate on interannual variability of terrestrial $\mathrm{CO}_{2}$ fluxes, Global Biogeochem. Cycles, 16(4), 1102, doi:10.1029/ 2002GB001928.

Thornton, P. E. (1998), Regional ecosystem simulation: Combining surfaceand satellite-based observations to study linkages between terrestrial energy and mass budgets, Ph.D. dissertation, 280 pp., Sch. of For., Univ. of Montana, Missoula, Mont.

Tian, H., J. M. Melillo, D. W. Kicklighter, A. D. McGuire, J. V. K. Helfrich III, B. Moore III, and C. J. Vörösmarty (1998), Effect of interannual climate variability on carbon storage in Amazonian ecosystems, Nature, 396, 664-667.

Trenberth, K. E. (1997), The definition of El Niño, Bull. Am. Meteorol. Soc., 78(12), 2771-2777.

Trenberth, K. E., and T. J. Hoar (1997), El Niño and climate change, Geophys. Res. Lett., 24(23), 3057-3060.

van der Werf, G. R., J. T. Randerson, G. J. Collatz, L. Giglio, P. S. Kasibhatla, A. F. Arellano Jr., S. C. Olsen, and E. S. Kasischke (2004), Continental-scale partitioning of fire emissions during the 1997 to 2001 El Niño/La Niña period, Science, 303, 73-76.

Wardle, D. A., G. Hörnberg, O. Zackrisson, M. Kalela-Brundin, and D. A. Coomes (2003), Long-term effects of wildfire on ecosystem properties across an island area gradient, Science, 300, 972-975.

White, M. A., P. E. Thornton, S. W. Running, and R. R. Nemani (2000), Parameterization and sensitivity analysis of the Biome-BGC terrestrial ecosystem model, Earth Interact., 4(3), 1-85.

Wolter, K., and M. S. Timlin (1998), Measuring the strength of ENSO events: How does 1997/98 rank?, Weather, 53(9), 315-324.

Yang, S., Y. Hou, A. J. Miller, and K. A. Campana (1999), Evaluation of the Earth radiation budget in NCEP-NCAR reanalysis with ERBE, J. Clim., $12,477-493$

H. Hashimoto, Graduate School of Agricultural and Life Sciences, University of Tokyo, Bunkyo-ku, Tokyo 113-8657, Japan.

W. M. Jolly and S. W. Running, NTSG, School of Forestry, University of Montana, Missoula, MT 59812, USA.

C. D. Keeling and S. C. Piper, Scripps Institution of Oceanography, La Jolla, CA 92093, USA.

R. B. Myneni, Department of Geography, Boston University, Boston, MA 02215 , USA

R. R. Nemani, NASA Ames Research Center, Mail Stop: 242-4, Moffett Field, CA 94035, USA. (ramakrishna.r.nemani@nasa.gov)

M. A. White, Department of Aquatic, Watershed, and Earth Resources, Utah State University, Logan, UT 84322, USA. 